\title{
PHENOMENOLOGY, HERMENEUTICS AND PSYCHOTHERAPY
}

\section{Professor HG Pretorius}

D. Litt et Phil.; Rand Afrikaans University

\section{Dr AM Segal}

D. Litt et Phil.

\section{ABSTRACT}

This paper suggests some avenues that the conscientious psychotherapist may choose to adopt in order to answer the question: "Who is that person over there called "the patient"?" Traditional and contemporary obstacles that stand in the way of the clinician obtaining a clear and accurate understanding of the patient's experience are discussed with reference to the Cartesian dichotomy. Solutions to the problem of the split between subject and object are suggested using hermeneutic principles within an existential - phenomenological framework.

\section{ABSTRAK}

Hierdie artikel stel moontlikhede voor wat die konsensieuse psigoterapeut kan gebruik om derhalwe die volgende vraag te beantwoord: "Wie is hierdie persoon wat ons die "pasient" noem? Tradisionele en kontemporêre struikelblokke wat die klinikus inhibeer om 'n suiwer en akkurate begrip van die pasiënt se ervaring te verkry word bespreek, me spesifieke verwysing na die Cartesiaanse digotomie. Oplossings vir die probleme van tweeledigheid tussen onderwerp en voorwerp word voorgestel met die aunwending van hermeneutiese beginsels binne ' $n$ eksistensieel-fenomenologiese raamwerk.

Zu den sachen selbst (Back to the things themselves) - Edmund Husserl (1859 - 1938)

\section{INTRODUCTION}

As far as is known, humans are the only creatures who are aware of being aware. From this miraculous quality of subjectivity comes their capacity to have intentions, to interpret experience, and to discover and create (Bugental, 1989). The subjective view of mankind, which refers to the internal or personal realm of experiencing (including processes such as values, intention, dreams, fantasy and love), began to be feared early this century by those adopting a natural scientific approach to knowing the world and the psychology of its inhabitants (Bugental, 1989).

This paper suggests some avenues for the psychotherapis faced with this question: "Who is this person called the 'patient'?' Firstly, certain obstacles that stand in the way of the psychotherapist obtaining a clear and accurate understanding of the patient's experience with specific reference to the Cartesian dichotomy, will be discussed. Thereafter solutions to the problem are suggested using hermeneutic principles within an existentialphenomenological framework.

\section{CARTESIAN DUALISM}

Many of the troubles experienced in the attempt to understand man could be attributed to the French philosopher Rene Descartes, (1596 - 1650) after whom the term 'Cartesian dualism' is coined. Cartesian dualism fosters the idea that objective reality can be mor accurately known by an observing subject and identified, 
measured and predicted by rational scientific processes rather than by the subject getting to know reality through directly and intuitively experiencing it.

According to Descartes' rules of logic, nothing was ever to be accepted as true if there was no evident knowledge of its being so. He noticed that while trying to think everything false, that he who was thinking was something true.

While the human sciences shuddered, Descartes, with his famous words, "Cogito Ergo Sum" (I think, therefore I am), succeeded in introducing a form of philosophical dualism between body and mind, and subject and object that continues to plague psychology and presents a obstacle to any meaningful and proper understanding of the nature of man. This objective view of psychology, which views only that which can be measured as 'real', was a nail in the coffin in which a psychology, aimed the understanding of man's experience, was ruthlessly buried. The philosophical dualism of Descarte (Cartesian dichotomy) distances man from his environment to the extent that it conceives of man as an encapsulated, thinking subject (res cogitans) in opposition to the world of things (res extensa). Man is viewed as existing separately from the world in which he lives.

Cartesian dualism ignores the complex and interrelationa nature of man and his environment and the interplay between the 'knower' and the 'known'. Research into the nature of man is in this way deprived of essentia knowledge, and information about 'what it is like to be human' is overlooked or lost. The need for change in this dualistic way of understanding man is suggested by Koyre (1966:xxxiii) who writes: "Descartes has, by his insistence on clarity and distinction ... destroyed the well ordered, rich and colourful cosmos of ancient and medieval science..." (in a forward to Descartes' philosophical writings)

Koyre sounds a pessimistic note and seems at a loss as to how to accomplish a more meaningful approach to the study of man. He continues: " ...we have reache the region where some kind of mixed thinking must be applied, where we have to think about mind in terms of body, and body in terms of mind. Along both ways we must go as far as possible. Yet they will never join." (in a forward to Descartes' philosophical writings, 1966:xxxiii).

\section{DIAGNOSIS WITHIN CARTESIAN} DUALISM

A major obstacle that has emerged, in recent years, to the understanding and interpretation of the patient, has been the advent of the generation of diagnostic manuals.

Since the first classification of mental illness was introduced in 1840 , various attempts have been made to classify mental disorders.

The first edition of the Diagnostic and Statistical Manual f Mental Disorders (DSM-I) was published in 1952 and the shadow of Cartesian dualism is suggested by the use of the word 'reaction' throughout the DSM-I. This word reflects the notion that people react to their surroundings and stand apart from them.

The term 'reaction' was omitted in DSM-II (perhaps in an attempt to appease an emerging group of phenomenologically orientated clinicians. The latest manual, the DSM-IV, is characterised mainly by the addition of new diagnostic categories to include groups of individuals, which were not covered in DSM-IIIR. The task force that worked on the development of the DSM-IV, admits to the manual's inadequacies and states: "No classification of mental disorders can have a sufficient number of specific categories to encompass every conceivable clinical presentation." (APA, 1994:xx).

However, mental health experts continue to remove the patient from his or her context by resorting to the proces of fitting him or her into a 'mental illness' category. In a cautionary statement, the task force says that the purpose of the DSM-IV is "to provide clear descriptions of diagnostic categories in order to enable clinicians and 
investigators to diagnose, communicate about, study, and treat people with various mental disorders." (APA, 1994:xxvii). Nowhere does it refer to the manual as being able to assist with the "understanding' of the patient. It may be said that patients were non-participatory in the formulation of the DSM-IV in the sense that there appears to be little attempt made, in over eight hundred pages, to describe and translate patients' experiences into meaningful appraisals of their situations. There is no reference to embodied experience or the body-as lived.

Halling and Goldfarb (1996) describe the diagnosing of people with social and interpersonal problems as being inappropriate and damaging. Classification or "pigeonholing', they write, dehumanises by disregarding the uniqueness of each individual. Bugental (1988) writes that when patients bring to therapists their 'living' and we treat them as symptoms, habits, problems and diagnostic categories, they are betrayed. Regarding the DSM-IV, Phillips (1996:67) writes that the manual either represents the "best conclusions of a group of historically conditioned experts ... or $\ldots$ the prejudices of a group of experts who currently hold power in the psychiatric establishment". He states that he cannot accept a position that the DSM-IV or any other diagnostic system, is purely and simply, 'the truth'. Lest we relegate the idea of 'understanding' to the halls of academia, we are reminded by Phillips (1996) that the purpose of understanding is the achievement of a practical goal, which is to treat the patient.

HERMENEUTICS IN AN EXISTENTIAL -PHENOMENOLOGICAL FRAMEWORK

It seems that an approach, different from that which is influenced by radical scientific notions concerning the nature of man, is required in understanding the patient. Echoing the central theme of the phenomenological philosopher Edmund Husserl, a different perspective from that of the 'objectivists' has emerged, which calls upon those who would know the true nature of reality to set aside their theories and preconceptions and to go back to the things themselves, to life as it is actually experienced (Valle, King \& Halling, 1989). This style of thinking is called 'phenomenology'. Together with existentialism the existential-phenomenological approach toward the study of man and his world avoid the problem of Cartesian dualism. This undercuts the split between subject and object, and leads to a deeper and fuller understanding of human existence (Valle et al. 1989).

Existentialism and phenomenology are complimentary approaches to the study of man in that the phenomenological methods underlie existential philosophical inquiries. Together, phenomenology and existentialism form the philosophical discipline known as 'existential phenomenology'. When applied to human psychological phenomena, existential phenomenology becomes 'existential-phenomenological psychology, which can be defined as a psychological discipline that seeks to explain the essence, structure or form of human experience and behaviour through using descriptive research techniques (Valle et al. 1989).

The marriage of existentialism and phenomenology occurred in urgent response to the dilemma caused by Cartesian dualism and the 'predicament' in which man distanced from his surroundings, found himself. The coconstitutionality of man and his world is often referred to as his 'life-world'. The life world is an imperfect, but often used, translation of the German word 'Lebenswelt'. This term refers to man's naive experience of his world, i.e. the world of pure phenomena, independent of and prior to any reflective interpretation, whether it is scientific or otherwise. The Lebenswelt is the beginning of knowledge (Valle et al. 1989). It is first pre-reflective and later gives rise to reflective awareness and vice-versa in a circle (Valle et al. 1989). This ultimately leads to an understanding of the structure of the phenomena. The structure of a phenomenon consists of the common threads running through the many ways in which the phenomenon appears to the observer (Valle et al. 1989). In order to understand the structure of a given phenomenon one's preconceptions and prejudgments of it have to be suspended. This is done by a process called bracketing" during which process "That which is of the 
prereflective level becomes accessible at the level of reflective thought" (Valle et al. 1989:11). Bracketing and rebracketing continue in a circle during which time one moves from the 'natural attitude' toward the 'transcendental attitude', the latter known as the 'phenomenological reduction'. The process of bracketing never ends, because as one becomes more aware of one's prejudices, other prejudices emerge. The task of the existential-phenomenological psychologist is to disclose the nature of the structure of a phenomenon in the form of meaning (Valle et al. 1989). The psychologist does so, whether consciously or unconsciously, by relying upon hermeneutics. Hermeneutics is a discipline concerned with interpretation and meaning. Hermeneutics is used to translate phenomena into meaningful knowledge by relying upon hermeneutic principles (Valle et al. 1989). This is believed to be achieved with the minimum of subjective bias.

In an attempt to resolve the Cartesian dichotomy, the aspects of hermeneutics and existential phenomenology will now be discussed.

\section{ALTERNATIVE APPROACHES}

Before embarking upon the requirements for a different approach to understanding the patient's experience, a caveat is offered against succumbing to the attraction of single perspectives that claim to encompass the whole of human reality.

Wiggins and Schwartz (1997:279) remind us that it is not uncommon for a proponent of one perspective to champion it as the 'most basic', or as the 'master' perspective. Accordingly, they warn that 'hermeneuticians' would be making a fatal mistake to conclude that the hermeneutic perspective is the sol fruifful viewpoint on reality. They state categorically: "No perspective, then, can provide the 'master' allembracing theory of human reality." This said, any scholarly undertaking should begin with conceptualising of its subject matter. Failure to do thi results in, as Martin and Thompson (1997:630) put it, psychology putting its "epistemological/methodological cart ahead of its ontological/substantive horse".

\section{PHENOMENOLOGY}

The term 'phenomenology' can be so broadly defined and understood that, according to Richardson (1980), certain chosen narrowness of definition of its meaning is essential if it is to be useful to a predetermined purpose The term 'phenomenology' has been used since the mideighteenth century and is used to refer to a homogeneous and systematically developed philosophical position. In contemporary philosophy, there is no system or school alled 'phenomenology' characterised by a clearly defined body of teaching

It is rather a movement that has been propelled in many distinct directions with the result that, today, it means different things to different people. Phenomenology is transcendental philosophy interested only in what is "left behind' after the phenomenological reduction to the essence of the phenomena has been performed. Phenomenology is an attempt to give a direct description of experience as it is, in itself, without taking into account its psychological origin and its causal explanation.

Merleau-Ponty (1962) has referred to phenomenology a transcendental philosophy which uses a style of hinking that concentrates upon re-achieving a direct and primitive contact with the world by rejecting traditional ways of understanding man and by suspending preconceived notions about man's true nature. MerleauPonty (1962:vii) explains:

"Phenomenology is the study of essences... it is also a philosophy for which the world is always 'already there' before reflection beings ... and all its efforts are concentrated upon re-achieving a direct and primitive contact with the world ... it tries to give a direct description of our experience as it is, without taking into account its psychological origin and the causal explanations which the scientist, the historian or the sociologist may be able to provide." 


\section{EXISTENTIAL-PHENOMENOLOGY}

In his introductory chapter to the book by May, Angel and Ellenberger, May (1958:11) attempts to define existentialism as "... the endeavour to understand man by cutting below the cleavage between subject and object which has bedeviled western thought and science..." and refers to existentialism as being concerned with the science of 'being'. In his classic introduction to the origins and significance of the Existential movement in psychology, May (1958) writes: "what is required is an approach to the world which undercuts the "cancer' namely, the traditional subject-object dichotomy" (in May et al. 1958:56).

Existentialism is an approach, which, like phenomenology, tries to overcome the philosophical dualism of the subject-object dichotomy. It attempts to do so by holding that the person and his world form a unitary, structural whole. May (in May et al. 1958:59) expounds on this idea as follows: "The two poles, self and world, are always dialectically related. Self implies world and world self; there is neither without the other, and each is understandable only in terms of the other."

Clarifying statements, in this regard, are made by Merleau-Ponty (1962:5) who writes, "man is not inside us, there is no interior man, man is in the world and it is by this world that he becomes manifest". Similarly, Chessick (1986:88) postulates that "there is no separate ego - a person is always interrelated with the world of things and other persons"

\section{HERMENEUTICS}

Hermeneutics is the science of interpretation, especially of scripture. It is a branch of theology that deals with the principles and methodology of explanation or critical interpretation of a text, usually of the Bible (Collins English Dictionary). The roots of the word 'hermeneutics' lie in the Greek verb 'hermenenein' that can be generally translated as meaning 'to interpret'.

Palmer (1969) defines hermeneutics as the task of understanding, with specific regard to understanding texts. Palmer (1969) also points out that in the reading of a message or a text, there is, at the very least, an automatic and spontaneous interpretation of its meaning. Understanding a text relies on the interpreter's personal, existential engagement with the text, in addition to an academic or intellectual approach to it. With regard to a work of art. Palmer (1969:9) writes: "a work of literature is not an object we understand by conceptualizing or analyzing it; it is a voice we must hear, and through "hearing' (rather than seeing), understand." Romanyshyn (1991) points out that knowing involves complex processes, which he calls 'psychological gnosis', and he distinguishes these from 'empirical gnosis' Psychological gnosis, he points out, is characterised by:

“... indirections and distortions, by twists and turnings, by allusions and displacements which indicate that we know only through our complexes, and which betray, therefore, the complex character of our knowing." (Romanyshyn, 1991:10). These sentiments, extended to the field of mental health, are echoed by Phillips (1996) who recognises that there is no value-free or presuppositionless orientation in the field of mental health

\section{RESOLVING THE CARTESIAN} DICHOTOMY

Phenomenologists try to resolve the Cartesian dichotomy by attempting direct, prejudice-and-judgement-free experiencing of phenomena. The German philosopher Husserl instructs us to let the phenomenon speak for itself. "Back to the things themselves", writes Husserl (1901)

\section{BRACKETING}

As a philosopher, Husserl (1901) advocates the letting go of preconceptions and all received ideas so that a wider perspective and openness can be achieved. This process is known as 'bracketing' or the phenomenological 'epoch' (which is the Greek for bracketing) or the phenomenological 'reduction' (Polkinghorne, 1989). Bracketing is the abstention from positing the existence of the 'natural' world around us as existing independently 
of the human experience of it. By carrying out the reduction (or bracketing) the world is no longer taken for granted, but is understood in terms of the 'phenomenological' or what is sometimes referred to as the 'transcendental attitude' (Valle et al. 1989) Husserlian phenomenology is used to analyse consciousness as opposed to giving an account of its causal origins in brain activity or elsewhere. Consciousness is to be studied precisely as it is experienced and the objects that are given to this experience are, accordingly, also to be characterise precisely as they are given, with no metaphysical interpretations. It is in this sense that we are to understand Husserl's slogan: "(Back) to the things themselves!" Bracketing is close to the Zen idea of "realizing original mind' or what is sometimes called 'no mind'. In describing a conceptualisation of experiencing the world, Van Den Berg (1981:34) writes "it is not out there in the world that all of what we call subjective takes place. In the things, in the objects around us we find our inner being". Similarly (Valle, 1989:258) states: "intentionality directly addresses and reflects the fel quality of what we normally describe as our consciousness, awareness, or experience, and its contents".

From a phenomenological point of view the, the world in which man lives, by virtue of the fact that he experiences it or intends it, is experienced differently from the world as measurable Cartesian extension. Phenomenology and existential-phenomenological psychology, by avoiding the subject-object split, claims as their main contribution, an approach, which leads to a rich and full understanding of human existence.

\section{HERMENEUTICS AND PSYCHO- THERAPY}

It is not the ambition of every therapist to attempt to know that person sitting over there called 'patient'. Hychner (1993) describes a dialogical approach as one in which the willingness of the therapist to enter fully into the subjective experience of the client is paramount. He regards it as both a bedeviling and intriguing challenge to the therapist. In each instance, the patient's unique meaning will be molded by his different ways of "beingin-the world'. Hychner (1993) writes that the therapis cannot truly enter the world of the patient unless he is prepared to suspend his presuppositions and he equates this process with bracketing. This involves the therapist "emptying out of his taken for granted meanings." (Hychner, 1993:125). He is not alone in pointing out the futility of attempting to achieve a complete suspension of the therapist's perspective, or the futility, for most of us, of attempting to attain complete 'empty mindedness', as is believed to be possible, for example, in the Ze Buddhist tradition. Tappan (1997:653) writes: “... the interpretive process is never value neutral, but always consists of value judgements grounded in the interpreter's own ethical and political commitments."

How then can we approximate the entering of the patient' world without being unduly influenced by this ultimate truth? Can hermeneutics be of use in achieving this noble knowing of the patient's internal psychological terrain? Packer (1985) believes that hermeneutics seeks to clarify and explain the understanding of human actions by interpreting them. It is suggested by Valle et al. (1989) that substituting the words 'behaviour', 'situation', 'client' or 'data' for 'text' or 'iterature', may illuminate the part that hermeneutics can play in psychology. In other words, the same processes used in understanding and interpreting text and that result in knowing the text, can be used in knowing the patient.

Palmer (1969:10) is of a similar opinion. He says the wrestle with the phenomenon of understanding goes beyond the interpretation of text and gives a "... potentially broad significance for all those disciplines customarily called the humanities." Referring to hermeneutics, he writes that its principles comprise a theoretical foundation for the humanities. Referring to clinical psychiatry, Wiggins and Schwartz (1997:280) write that it "always moves within the hermeneutic circle in which the therapist takes what the patient is doing and seeks to discern the experiences expressed by it." Two specific hermeneutic principles, the 'hermeneutic circle' and 'pre-understanding', illustrate the implications of 
hermeneutics for psychology and psychological research (Valle et al. 1989). Firstly, Dilthey's hermeneutic circle described by Tappan (1997) is based on the idea that understanding is fundamentally inductive. A general law is not deduced by a series of incomplete instances, bu rather from a series of instances which are seen as representing a larger whole. He quotes Dilthey as saying that the whole of a work must be understood "... from individual words and their combination, but ful understanding of an individual part presuppose understanding of the whole...the whole must be understood in terms of its individual parts, individual parts in terms of the whole..." (Tappan, 1997:648) Tappan (1997) further points out the similarity between Dilthey's hermeneutic circle, used to interpret text, and a dialectic that exists between two people trying to understand one another. When a text is initially read, the investigator sees or reads only part of it, and this results in some misunderstanding, because a sense of the whole is lacking. As the investigator develops a sense of the whole, he comes to understand the parts. The process of moving between the parts and the whole and back again is referred to as the hermeneutic circle and results in an increasingly deeper insight into the text as the text is read over and over (Valle et al. 1989).

Secondly, the investigator's pre-understanding of the text will deepen his understanding of the text. It is critical that investigators be ready to ask certain questions about heir own pre-understanding of the text. Valle et al. (1989:16) suggest asking questions such as "what have I already assumed which may account for my failure to make sense of this section?" and "are there specific assumptions which this writer takes for granted, and which someone from my tradition would not take for granted?" This process of self-reflection is one in which the researcher becomes aware of his prejudices and preconceptions and is similar to the process of bracketing (Polkinghorne, 1989).

In hermeneutics then, a text is read over and over again to improve understanding. The reader moves between the parts and the whole, and gains an increasingly deeper insight into the text as the hermeneutic circle continues.
Romanyshyn (1991:14) suggests giving up all efforts to make sense of a text, for example, by not resorting to highlighting it. This allows one to give one's "undivided and evenly hovering attention" to the entire text and does justice to this hermeneutic principle by avoiding premature closure. Similarly, the psychotherapist can go over and over the patient's physical presentation and language, without jumping to conclusions and without deriving formulations or categories by which to describe the patient. Premature closure is avoided in this way and the possibility arises of the patient becoming accurately 'known' to the therapist.

The second hermeneutic principle is one in which the reader deepens his understanding of the text by being aware of the influence of his own pre-understanding on his grasp of the text. It is important for the reader to reflect upon his prejudices and preconceptions.

Phillips (1996) states that, unlike the object of scientific investigation, the object of human studies comes 'reinterpreted'. That is, patients have ideas about themselves before the mental health expert interpret them. Man is a self-interpreting animal. There are two levels of interpretation, the first by the patient, the second by the therapist. The patient brings in a 'life-story' or self-interpreted narrative, which is an attempt to make sense of his or her suffering (Phillips, 1996). According to Phillips (1996:66) the goal of therapy "becomes the re-organization of these meaning structures. With and through the therapist a new set of meanings, a new narrative, is developed." Even where biologically based conditions such as schizophrenia and bipolar illness are present, the illness still means something to the patient.

Phillips (1996) raises interesting questions such as: is the meaning the patient gives to the illness somewhat independent of the illness or a product of it? Is the patient's thinking always thought-disordered? Does the patient have sufficient distance from the illness to be able to interpret it in a useful way? There is an obvious difference, he say, between "a schizophrenic who can discuss his or her illness and another whose thinking is so invaded by the illness that such a discussion is not 
realistic" (Phillips, 1996:66). He then writes that it is the clinician's task to sort through these questions, since issues of compliance with treatment depend on this.

\section{CONCLUSION}

The phenomenological approach views the patient and not the disorder as the unit of investigation. It is no helpful, write Halling and Goldfarb (1996), to view symptoms as caused by some internal or external agent acting independently of the person's intentions. Symptoms are understandable, unsatisfactory attempts to deal with psychologically disturbing situations (Halling \& Goldfarb, 1996). Halling and Goldfarb (1996) sugges that therapists acknowledge and be aware of a least these five principles of phenomenological practice:

- There are varying styles or patterns of human behaviour;

- Behaviour is purposeful, even when it is symptomatic;

- It is essential to understand the context in which behaviour occurs;

- It is essential to understand the context in which diagnosis takes place; and

- It is essential to be aware of the presupposition that get in the way of understanding the patient.

The last point can be honoured by applying the second hermeneutic principle that requires that the therapist be ware of personal prejudices and makes the attempt, if possible, to suspend them. An example of failure to do this is given by Halling and Goldfarb (1996:69) who write that it is "too easy for a skeptically inclined psychologis to interpret a patient's renewed interest in religion as a mere retreat from reality, just as a devout psychologist may too uncritically welcome such an interest as a sign of increased hopefulness."

The philosopher and literary historian, Wilhelm Dilthey, $(1833-1911)$ is generally recognised as the 'father' of the modern hermeneutic enterprise in the social and human sciences (Tappan, 1997). The key to Dilthey's conception of hermeneutics is the relationship between experience, expression and understanding (Tappan,
1997). If an experience is to be understood it must firs be expressed. An expression can be anything that expresses the lived experience of human beings including a story, a poem, a painting, architecture, a film, a dance, a piece of music and an idea (Tappan, 1997). Should we not therefore heed the remarks of Ulysses, referring to Cressida in Shakespeare's play 'Troilus and Cressida' "There's a language in her eye, her cheeks, her lip, Nay, her foot speaks: her wanton spirit looks out at every joint and motive of her body." (Shakespeare, 1602, Ac $1 \mathrm{~V}$, scene $\mathrm{V}$, lines $82-86$ ).

\section{LIST OF REFERENCES}

AMERICAN PSYCHIATRIC ASSOCIATION 1994 Diagnostic and statistical manual of mental disorders; $4^{\text {th }}$ edition. Washington, DC: Author

BUGENTAL, FT 1988: What is failure in psychotherapy? Psychotherapy, 25:532-535.

BUGENTAL, FT 1989: In: RS Valle and S Halling eds. 1989: Existential phenomenological perspectives in psychology: exploring the breadth of human experience New York: Plenum Press, pp. ix-xi.

CHESSICK, RD 1986: Heidegger for psychotherapists. American Journal of Psychotherapy, EL, 1:83 - 95.

HALLING, S \& GOLDFARB, M 1996: The new generation of diagnostic manuals (DSM-III, DSM-IIIR, and DSM-IV): An overview and a phenomenologically based critique. Journal of Phenomenological Psychology, 27(1):49-71.

HUSSERL, E 1901: Logische untersuchungen. (Logical Investigations), Vol. 2. translated by JN Findlay, 1970 New York: Humanities press.

HYCHNER, RH 1993: Between person and person toward a dialogical psychotherapy. New York: The Gestalt Journal Press.

KOYRE, A 1966: In: E Anscombe \& PT Geach eds. 
1966: Descartes: Philosophical writings. London: Thomas Nelson.

MARTIN, J \& THOMPSON, J 1997: Between scientism and relativism: phenomenology, hermeneutics, and the new realism in psychology. Theory and Psychology, $7(5): 629-652$.

MAY, R; ANGEL, E \& ELLENBERGER, HF 1958: Existence. New York: Basic Books.

MERLEAU-PONTY, M 1962: The phenomenology of perception. New York: Routledge \& Kegan Paul.

PACKER, MJ 1985: Hermeneutic enquiry in the study of human conduct. American Psychologist, 40(10):1081 -1093 .

PALMER, RE 1969: Hermeneutics: Interpretation theory in Scleimacher, Dilthy, Heidegger and Gadamer. Evanston, II: Northwestern University Press.

PHILLIPS, J 1996: Key concepts: hermeneutics. Philosophy, - Psychiatry, -and Psychology, 3(1):61 69.

POLKINGHORNE, DE 1989: Phenomenological research methods. (In: RS Valle \& S Halling eds. 1989: Existential phenomenological perspectives in psychology: exploring the breadth of human experience. New York: Plenum Press, pp. 41 - 60.)

RICHARDSON, WJ 1980: Phenomenology and psychoanalysis. Journal of Phenomenological Psychology, 2(2):1 - 19

ROMANYSHYN, R 1991: Complex knowing: toward a psychological hermeneutics. The Humanistic Psychologist, 19(1):10-29.

SHAKESPEARE, W 1602: Troilus and Cressida. (In: The Complete Works of William Shakespeare. London: Spring Books.)

SUZUKI. DT 1969: The Zen doctrine of no mind.
London: Rider.

TAPPAN, MB 1997: Interpretive psychology: Stories, circles, and understanding lived experience. Journal of Social Issues, 53(4):645-656.

VALLE, RS 1989: The emergence of transpersonal psychology. (In: RS Valle \& S Halling eds. 1989: Existential phenomenological perspectives in psychology: exploring the breadth of human experience. New York: Plenum Press, pp. 257 - 268.)

VALLE, S; KING, M \& HALLING, S 1989: An introduction to existential phenomenological thought in psychology. (In: RS Valle \& S Halling eds. 1989: Existential phenomenological perspectives in psychology: exploring the breadth of human experience. New York: Plenum Press, pp. 3 - 16.

VAN DEN BERG, JH 1981: Phenomenology and psychotherapy. Journal of Phenomenological Psychology, pp. $21-49$.

WIGGINS, OP \& SCHWARTZ, MA 1997: Commentary on "encoding of meaning". Philosophy, -Psychiatry, and Psychology, 4(4):277 - 282 